\section{Macrocalcifications in a thyroid microcarcinoma}

\author{
Adriana Handra-Luca', Frederique Tissier ${ }^{2}$ \\ ${ }^{1}$ APHP GHU Avicenne, Université Paris Nord Sorbonne Cite, Bobigny; ${ }^{2}$ APHP Hôpital \\ Universitaire de la Pitié-Salpetriere, Université Pierre et Marie Curie, Sorbonne Universités, \\ Paris, France
}

We have read with great interest the article by $\mathrm{Na}$ et al. [1]. Dystrophic macrocalcifications, although more frequent in benign nodules, may also occur in malignant thyroid tumors, along with the wellknown psammoma-type calcifications [1-4]. We recently had an opportunity to study a thyroid microcarcinoma with extensive calcification.

A 50-year-old man presented with an incidentally diagnosed calcified goiter on imaging procedures intended to evaluate rib fractures from a auto roll-over accident. The thyroid was enlarged (90 mm $\times 70 \mathrm{~mm} \times 27 \mathrm{~mm}$ ), plunging retrosternally into the mediastinum. The patient had also experienced generalized tonic-clonic seizures 13 and 3 years previously, and had been undergoing treatment with levetiracetam $(2 \times 500 \mathrm{~g} /$ day $)$ for the past 3 years. The patient's serum calcium, as well as the prothrombin time and activated cephalin time, fell within normal range. Thyroidectomy was performed, and the microscopic diagnosis was nodular goiter with fibrosis and dystrophic calcifications. A 3-mm encapsulated nodule was incidentally identified in the left lobe of the resected thyroid gland with extensive calcification comprising $75 \%-90 \%$ of the nodule surface on different tissue sections (supplementary Fig. 1). The tumor cells showed a vesicular arrangement, nuclear incisions, and inclusion, and they also diffusely expressed cytokeratin 19 (CK19). Several tumoral vesicles were directly surrounded by a calcified matrix, which also contained isolated nuclei. One focus of invasion was seen in the relatively thick capsule of the nodule. Dystrophic calcification was seen in a perinodular fibrous tract and in the colloid, as well as in a perithyroid blood vessel wall (von Monckeberg type). Postoperatively, calcemia was normal and a substitutive thyroid hormone treatment was started.

The origin of the dystrophic calcification in the thyroid microcarcinoma we report was difficult to precisely determine. The presence of a nodular carcinoma-specific microenvironment, characterized by the diffuse expression of the acid cytokeratin CK19 (OMIM 148020) in tumor cells, could be implicated in the genesis of the extensive, pan-nodular dystrophic calcifications. Moreover, several dystrophic nuclei were observed in the calcified matrix, suggestive of necrosis, also considered a pro-calcification microenvironment [5]. Hemorrhagia and hematoma are also considered procalcification microenvironments. In the case we present, both acute and chronic hemorrhagia-related lesions, such as fibrosis and pigmented macrophages, were present in the resected thyroid, including at the proximity of the calcified nodule. Moreover, a large malformed cavitary intrathyroid blood vessel, the origin of abnormal oxygenation and possible hemorrhage, was observed $4 \mathrm{~mm}$ from the calcified microcarcinoma. We concluded that dystrophic macrocalcifications may occur in thyroid microcarcinomas, more likely as a result of the tumor microenvironment than of systemic abnormal calcium metabolism.

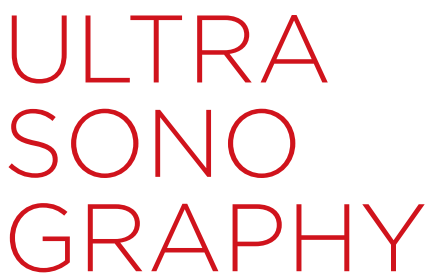

\section{LETTER}

http://dx.doi.org/10.14366/usg.16011 pISSN: 2288-5919 • elSSN: 2288-5943 Ultrasonography 2016;35:265-266

Received: February 24, 2016

Revised: March 3, 2016

Accepted: March 4, 2016

Correspondence to:

Adriana Handra-Luca, MD, PhD, Service d'Anatomie Pathologique, APHP GHU Avicenne, Universite Paris Nord Sorbonne Cite, 125 rue Stalingrad, 93009 Bobigny, France

Tel. +33-148955555 (ext. 52047)

Fax. +33-14895555602/5480 E-mail: adriana.handra-luca@aphp.fr

\begin{abstract}
This is an Open Access article distributed under the terms of the Creative Commons Attribution NonCommercial License (http://creativecommons.org/ licenses/by-nc/3.0/) which permits unrestricted noncommercial use distribution and reproduction in any medium, provided the original work is properly cited.
\end{abstract}

Copyright (C 2016 Korean Society of Ultrasound in Medicine (KSUM)

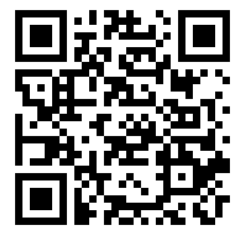

How to cite this article:

Handra-Luca A, Tissier F. Macrocalcifications in a thyroid microcarcinoma. Ultrasonography. 2016 Jul;35(3):265-266 
ORCID: Adriana Handra-Luca: http://orcid.org/0000-0003-3816-058X

\section{Conflict of Interest}

No potential conflict of interest relevant to this article was reported.

\section{Acknowledgments}

The authors thank the NCA/Avicenne, CDMP/APHP, and the BIUM teams.

\section{Supplementary Material}

Supplementary Fig. 1. Microscopic features of the thyroid microcarcinoma with extensive dystrophic calcification in a 50-yearold man (http://dx.doi.org/10.14366/usg.16011).

\section{References}

1. Na DG, Kim DS, Kim SJ, Ryoo JW, Jung SL. Thyroid nodules with isolated macrocalcification: malignancy risk and diagnostic efficacy of fine-needle aspiration and core needle biopsy. Ultrasonography 2016;35:212-219.

2. DeLellis RA, Lloyd RV, Heitz PU, Eng C. World Health Organization classification of tumors: pathology and genetics of tumours of endocrine organs. 3rd ed. Lyon: IARC Press, 2004.

3. Rosai J. Rosai and Ackerman's surgical pathology. Philadelphia: Mosby Elsevier, 2011.

4. Rosai J, Carcangiu ML, DeLellis RA. Tumors of the thyroid gland. Atlas of tumour pathology. AFIP 3rd series, fascicle 8. Washington, DC; Armed Forces Institute of Pathology, 1992.

5. Cotran RS, Kumar V, Collins T. Robbins pathologic basis of disease. 6th ed. Philadelphia:WB Saunders, 1999. 